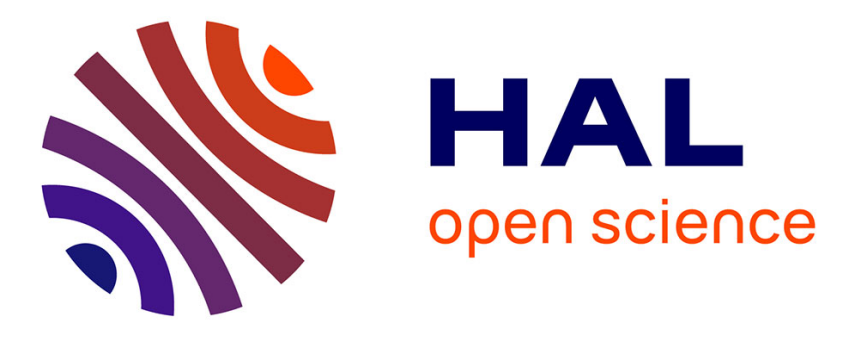

\title{
Edward Heath: The Failed Leadership of an Uninspiring Leader
}

Laetitia Langlois

\section{To cite this version:}

Laetitia Langlois. Edward Heath: The Failed Leadership of an Uninspiring Leader. Agnès AlexandreCollier; François Vergniolle de Chantal. Leadership and Uncertainty Management in Politics: Leaders, Followers ans Constraints in Western Democracies, 1, Palgrave Macmillan, pp.230-248, 2015, Palgrave Studies in Political Leadership Series, 978-1-137-43924-6. 10.1057/9781137439246_15 . hal02867676

\section{HAL Id: hal-02867676 \\ https://univ-angers.hal.science/hal-02867676}

Submitted on 15 Jun 2020

HAL is a multi-disciplinary open access archive for the deposit and dissemination of scientific research documents, whether they are published or not. The documents may come from teaching and research institutions in France or abroad, or from public or private research centers.
L'archive ouverte pluridisciplinaire HAL, est destinée au dépôt et à la diffusion de documents scientifiques de niveau recherche, publiés ou non, émanant des établissements d'enseignement et de recherche français ou étrangers, des laboratoires publics ou privés. 
Laëtitia LANGLOIS

Lecturer

Angers University, France

\section{Edward Heath: The Failed Leadership of an Uninspiring Leader}

The question of leadership in contemporary Western democracies is a fascinating subject for the historian as it explores the emergence of a man or woman and the unique relationship he or she builds with the people. Leadership is commonly associated to Max Weber's theory of "charismatic leadership" (Weber, 1995) and according to the French philosopher Jean-Claude Monod there is a persistence of the politics of charisma in contemporary democracies. (Monod, 2012: 58) Thus, leadership seems to be essentially construed around positive notions of power, success, domination and authority. Yet there exist other forms of leadership worthy of analytical study and the rationale of this article will be the failed leadership of Edward Heath. Edward Heath was Leader of the Conservative party for ten years, Prime Minister for four years and Member of Parliament for nearly fifty years, an incredibly long career filled with the most prestigious positions. Yet, nobody today remembers Edward Heath. The Conservative pantheon is inhabited by the great and imposing figures of Churchill, Macmillan or Thatcher but Edward Heath has completely disappeared from the Conservative memory. ${ }^{1}$. This is, a telling xclusion lies the utter and complete disaster of his years in power. Edward Heath is the embodiment of failure in a party that reveres success and glory. Yet he was certainly one of the most ambitious and, determined and hard-orking Primen had in the post-war years1960s and 1970s. He wairst talked of a devolved assembly in Scotland, the man who had Britain join the European Union in 1973, the man who launched a comprehensive reform of the trade-unions. But history only retains his failures and broken promises. Minor leaders tend to be completely cast aside by historians but those tragic figures of failure shed an original light on the question of leadership and help better understand the complex mechanisms at work between a leader and his followers.

Contradiction lies at the heart of Heath's leadership and his whole career is con followe any people inside his party. " (Blake, 299) nHeath always to opposite trends and always hesitated between two political personalities. Torn between a moderate progressive form o Conservatism and a more aggressive free market approach or torn between the status of the tough moderniser and the cautious man of consensus, in power Heath never really 
found his true self. and Robert Blake concludes that. "Edward Heath is not an easy person to categorise politically." (Blake, 1985: 299 and Campbell, 1993: xix)

1985: never realla moment of transition between two traditions, weof both the old and the new world and was trapped uneasily as one paradigm was beginning to lose itshe other mod het ture i or popular backing." (B

n. (Max Weber, Essays in Sociology, $19588+$ Economet ci

This chapter will focus on this instability at the heart of Heath's failed leadership asserting that all the difficulties and failures of his leadership stem from this division at the heart of his political identity and his incapacity thereof to project a coherent and clear image to his followers. Stephen Skowronek's theory of leadership ${ }^{2}$ will provide a useful framework to guide our analysis and will better highlight the structural contradiction of Heath's political nature. (Skowronek, 1993)

\section{I) Repudiation and emancipation: Edward Heath, the man of change}

In 1965, for the first time in its history, the Conservative Party organised elections to choose its leader and Edward Heath became the first leader ever to be democratically elected at the head at the Conservative Party. Compared to Reginald Maudling, his main contestant, Edward Heath stood out as a peculiar figure for he did not have the traditional Conservative profile: at 49, he was still a bachelor; he came from a modest background and had been educated in a grammar school. Politically speaking, Conservative MPs did not know much about him and his political stance. Two points nonetheless had singled him out from his colleagues. First, his European convictions were genuine and he conducted the negotiations for British entry in 1963 with much vigour and passion. Second, ceth much ardour and conviction in 1963. iIn 1964, in spitwn party, he succeded in having the system o rResale pPrice mMaintenance ${ }^{3}$ abolished. (See RamsdenBall and Sseldonm, 1980996: 2361) It was aA highly ontroverial masure considering that int against theoll shoppers (the taditional Conservative voters - ) but he stood firm judging that "[it] would show us to be a dynamic, modernising forc." (Heath, 1998: 260) A baclor, a grammar school boy, a passionate proEuropean, a protégé of Macmillan who could yet take harsh deohn Campbell, 1993: : ewas always an unusual politician. (p. xiv) : he t to the special relationshi wdie Maudling? Who were his followers and whattly did they follow? It is interesting to analyse the Heath

\footnotetext{
${ }^{2}$ In this book, Skowronek divides leadership into three main categories: articulation, repudiation and disjunction. The last two categories will be particularly helpful for our study of Edward Heath.

3 The resale price maintenance was a practice which consisted in having a fixed price imposed by the manufacturer and the retailer was not allowed to sell the product at a lower price.
} 
momentum in the summer 1965 because it gives an insight into the Conservatives' motivations.that led to his election. I would like to focus on the role of the press first and then on the mood in the party.

First, the press played a key role in Heath's election as head of the partyh Campbell insists on the fact that Heath received "flattering profiles bearing very little relation to reality." (Campbell, 1993: 190) He was presented as the young and tough moderniser, the champion of a new form of Conservatism and the representative of a new generation of politicians who would transform British politics. The Economist called him "the abrasive man of change" (The Economist, 31 July 1965); in other newspapers he was commonly defined as the "rough rider" or "the tiger in the party's tank.".(CPA, PPB 12, 26 July 1965) The press emphasised his modernising dimension and reforming spirit in order to instil a sense of novelty and renewal. A aft the unassuming leadership of Alec Douglas-Home, Heth was usually compared tampbell, 1993: p. 190) (This is the charas of myth-building the press revels). Every epoh needs a hero and in the summer 1965, Ted Heath was the press' new hero(See Dominic Sandbrook, 2006: 163 White Heat). Nothing could be more ridiculoung Ted Heath to John Kennedis not simply an amusing anecdote. It reveals the sense of collective expectation that was pervading Britain in the mid-1960s. In terms of economic power or international influence, Britain was lagging behind and everyone was waiting for the politician who would could restore Britain's dynamism and prestige. And to the press in general there was no doubt that this man was Edward Heath. It highlights the power the press already hadild or debunk a myth.It could be just amusing, but underneath, it reveals a thirst for renewal and a sense of expectation for

Yet, two years before he was not even a serious contestant and he was not particularly known to have a group of followers behind him. But in 1965, the situation was exceptional and circumstances worked in his favour: the Conservative party had lost an election and it needed not only a party leader but a Leader of Opposition capable of rivalling Harold Wilson. Ted Heath was not particularly known to have a grou $n$ difficult for the Conservativuse. tThe ConservativpParty has always traditionally considered itself " $t$ natural party of government in British politics" (Bale, 2010: 4) and that position was now being taken over by the Labour party. Thepresurover power wasimmense. (Ball and Seldon, 2005) Thus, oOne must point out the fundamentally pragmatic dimension of Heath's election. But, his followers were not people bound by a set of common convictions, principles, values and ideas. IiIdeas played no role in Heath's lection. Samuel Brittan ws amazed by the "extraordinarily small part policohn 
Campbell who reveals that "there was no ideological content to the contest at all." (Campbll, 993:p. 180). His follors were not people bound by a set of common convictions, principles, values and ideas. TheySo his followers were a very vague indistinct group of people more concerned with finding the right candidate to beat Wilson at the next election than electing a leader with a coherent set of policies./political programme. Jo 164) + (John Ramsden, 1996: 238The Making of) Considering these arguments, one must point out the fundamentally pragmatic dimension of Heath's election. Heath's choice was guided by the Conservatives' desperate attempt to come back to power. One must insist on the pressure in the Conservative Party has "traditionally considered itself to be the natural party of government in British politics." (Bale, 2010:4)s have always had a vision orty of power, and n was now being taken over by the Labour pareservations" (p. 166) among party members and adds that "the party had chosen him because it neede mrld (p. 199). The Conservaive Party did not arTed Heath but tded Ted Heathbecause he s

What Ramsden suggests here is that the Conservative Party did not choose a set of ideas and policies. They did not make their choice according to a political vision, what they chose instead was an image. After the outdated and anachronistic leadership of Alec Douglas-Home, the Conservatives were looking for a new image and Heath at the time was the perfect match. He was the young and tough moderniser, the champion of a new form of Conservatism and the representative of a new generation of politicians who would transform British politics. This was how the press presented him at the time: The Economist called him "the abrasive man of change"; in other newspapers he was commonly defined as the "rough rider" or "the tiger in the party's tank"4 to collective delusion. In order to polarise politics, in ore ol. Heath's election as the new Tory leader uneashed a torrent of fawning press interviews and flatat. There seems to be a consensus among historians on the major misunderstanding behind Heath's election.

First, difficult to really define his followers: modernisers, young Conservatives, but a very imprecthere was no ideological content to the contest at all." (p. 180) T

A few days after the election, The Economist underlined the party's opportunism and wrote a prescient paragraph on the party's attitude towards its new leader: 
"Mr Heath certainly carries radical hopes in his baggage. But in electing him the Tories have primarily shown their instinct for power. They picked, by a narrow majority, the man they reckoned most likely to bullock their way back into power. They will remain united behind him just as long as his pursuit of power looks promising." (The Economist, 31 July 1965)

Pragmatism and ambition made Heath's election, not enthusiasm, admiration or fascination. Heath's choice was guided by the Conservatives' desperate attempt to come back to power was now being taken over by the Labour party. Sense hat the start, the union of his followers reste had chosen him because it was told it needed someone like him to lead it in the modern world (p. 19did n Ramsden, The Making of) From te start, the union of his followers rested on a very fragile basis d ed Ted Heath but they needed Ted Heath because he was, as Tim Heppell explains, "a symet to 10 Downing Street. Thanks to him, the party hoped to widen its electorate and get rid of its elitist image, thereby increasing its chances of reelection. Heppell also argues that Heath was "an instrument of modernisaion and meritocracy" thanks his lower-middle Tensions also aroused around the theme of modernisationderived from another point: modernisation that was Heath's class ori' reveals that Heath had a purely utilitarian function in the party. pet theme and leitmotiv. Heath had been elected to project a modern imagen image of modernity but modernisation was still a concept that many Conservatives considered with muc change in a party that defs tuardnal continuity." (Layton-Henry, 1980: xiii) This does not mean that the party is oppochange,only conceives slow and gradual change. city for adaption (after historical defeat in 1 real nature of the Conservative ty

is th a subtle and "“dialogue beteen the themes of continuity and change." (Norton and\&Aughey, 1981: 13) Thus,asilieisapacity for adaptation and change nonetheless does not supersede an atavistic attachment to the past and nd heritage. "the continuing dialogue between the themes of continuity and chang This sui essencethe very identity of the Conservative Party but it is also the most complex feature of the party asassertion emphasises: "the desire to conserve is compatible with all manner of change, provided only that ch continuity." (Scruton, 1980:p. 22) BTherefore, being leader of the Conservative party then requires considerable dterity/deftness/skilsubtlety + an acute awareness that the past is not to be dispensed with but rt guide to themaking of policy of the revehe past, legacy, forefathers of the party. and the Conservatives had chosen the "man who was supremely ill-equipped 
Though an admirer of Harold Macmillan, Heath did not envisage, at the beginning of his leadership, to follow in his predecessor's footsteps. Macmillan was a political father but Heath was not at the head of the party to perpetuate a tradition but to open a new chapter and

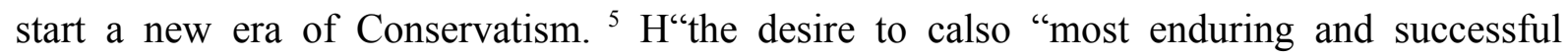
feature." (Norton \& Aughey, p. 13) But UHeath, upon being elected, Heath was not sonessentil believed that common sense, political will and some dose sufficient elements to make Bitairosperous again. (Douglas 12) He lacked one fundamental quality as far the Conservative party was concerned: the sense of history, the senseg the inheritor of a long and respected tradition of values, themes and ideals. Interestingly, Gamble explains that Heath was a man "who rejected Conservatism as a political philosophy and argued that a Conservative party, to be an effective political force, had to turn its back on the past and become a party of progress." (Gamble, 1974: p. 91)

exs autobiogrervatism on the party and, in time, to make a bid for the job that would enable me $\mathrm{t}$

political philosophy ofin the partl, p. 193:interest inolsophy or economic theory." Heatentially believed that common sense, politrespected tradition of ideals, values and themes. Andrew Gamble, p. 91: ...who rejected Conservatism as a political philosophy and argued that a Conservative party, to be an effective political force, had to turn its back on the past and become a party of progress."

Stephen Skowronek raises the concept of 'repudiation' to describe the process of emancipation that animates a new leader wishing to impose his signature on the party. Repudiation is what best characterises Heath's intentions and state of mind when he became Leader of the Conservative Party. "I now had the chance to stamp my brand of Conservatism on the parr c, human and political.

Soon after he was elected, Heath sent a letter to the Conservative Central Office indicating that he no longer wanted the term 'Tory' to be used but instead insisted on the use of the term 'Conservative'. (CPA, CCO 4/10/152, 15 December 1967) The term 'Tory' conveyed an outdated image he wanted to get rid of. Also, during his years as Leader of the Opposition, from 1965 to 1970, reading all his speeches nowhere did I find a single reference to the One Nation tradition (CPA, PPB 14-17). He never mentioned this term which was so closely associated to the great figures of post-war Conservatism such as Churchill, Butler or Macmillan. One Nation Conservatism is a branch of the Conservative partyy which enorsed

\footnotetext{
5 "I now had the chance to stamp my brand of Conservatism on the party and, in time, to make a bid for the job that would enable me to change the course of British history." (Heath, 1998 : 269)
} 
the post-war consensus and was primarily concerned with guaranteeing a fair and decent way of life to all citizens. One Nation ConservativesThey beliein Keynesian economics in the sense that, to them tethe State had a major role to play as protector of its citizens. One Nation was a direct reference to Benjamin Disraeli, their icon, and they profoundly believed in a set of values such as social justice, prosperity for all and national cohesion . Seeen, 2002: 247-8) Philip Norton and Arthur\& Aghey sum up the One Nation philosophy as the reconciliation of thebel role of theatead a set a values inherited from Benjamin Disreali, sin conhey, 1981: 78) One Nation Conservatives were primarily concerned with reconciling an industrial democracy with social justice and fairness. (Norton \& Aughey, 60) Edward Heath was f identifying hmself with th he play it down in order to project a more radical image. TheIt's a concept that resurfaced later, during his premiership when troubles increased significantly and tradition appeared a useful tool to unify the party and the nation. But at the beginning of his leadershiseems thadition was like a burdensome millstone round his neck. He did not consider at this time that there could be a clever balance between a respect for tradition and an impetus for modernisation.

Repudiation was not just symbolised by the change in names but also by the change in people. Hardly a year after his election, Heath changed many men in the Shadow Cabinet with an avowed objective of marking "a particularly significant stage in the transition towards a modern party." (Heath, 1998: 283) Some old warhorses such as Selwyn Lloyd, Duncan Sandys, John Boyd-Carpenter had to leave and were replaced by younger people who were to become - except one - Heath's closest colleagues: Robert Carr, William Whitelaw, Peter Walker, Margaret Thatcher. Edward du Cann left the chairmanship of the party and was replaced by Anthony Barber (who was to become Heath's loyal Chancellor of the Exchequer). (RamsdenCamp963: p 23 or

Novelty was sought but also and again a desire to impose a team in his own image. Heath introduced a group of men he knew well and trusted for they had the same background and did not pose any threat. This group of men would be later known as the 'Heathmen' and became even more important when hostilities grew between Heath and the rest of the party. ${ }^{6}$ (Roth, 1972)

Finally, in terms of policies, Heath had a grand plan of reform and was determined to present a whole new program that would, as he wrote in a letter, "break our links with the past and build a new framework of policies" in order to achieve "a fairly fundamental shift."(CPA,

\footnotetext{
${ }^{6}$ This group of men was composed of Anthony Barber, Peter Walker, John MacGregor, William Whitelaw. Some of them held important responsibilities in his future government.
} 
LCC Papers, 4 February 1970) To do so, Heath decided to retain all the posts he had held prior to his election. He continued to supervise the Economic Policy Group; he also stayed at the head of the Advisory Committee on Policy until 1968 and continued to control the Conservative Research Department together with Michael Fraser. He kept absolute control of the most strategic spheres of policy-making inside the party so much so that John Ramsden observes, "Heath had more personal monopoly of authority in the Party than any leader before him since Neville Chamberlain." (Ramsden, 1996: 235) The modernisation of the Conservative Party in his own image was at the roots of his commitments to politics. $\mathrm{He}$ exploited this monopoly to work out a new program of radical policies. The document entitled Putting Britain Right Ahead was issued in 1965 and contained the main aspects of Heath's Conservative society. (CPA, CCO 600/12/7, 1965) It presented a discourse based on dynamism, competitiveness and excellence. Heath's project was very clear: a European Britain whose prestige would lie in a dynamic economy and a competitive modern industry. Thus, the maintenance of the post-war consensus no longer seemed a priority compared to Britain's economic excellence. Slashing public spending, reducing budget deficit and curbing inflation became the new priorities in Heath's Conservative discourse. As such, we can side with John Campbell when he affirms that his economic programme at the time was "protoThatcherite" (Campbell, 1993: 267), hence the disappearance of the One Nation concept from his vocabulary to better enhance the impression of a radical departure. Another major twist was the overriding importance of Europe in Heath's vision: his ambition and greatest cause were to secure entry in the European Union to enjoy the benefits of the Common Market and emancipate the country from its historic ties with the Commonwealth and the USA. (Heath, 1998: 361)

With the publication of Putting Britain Right Ahead, Heath not only wanted to impose his vision of Conservatism, he also wanted to cultivate the image of the innovator, the pioneer, the modern man. Heath saw himself as a risk-taker, a man of action whose role was to jostle the party out of its tranquillity and traditionalism. But not everyone in the party was satisfied with this sweeping behaviour and his irreverence towards the past dismayed many a Conservative. The Times reported an episode that illustrates this malaise inside the party. Lady Douglas-Home visiting a local constituency was applauded frantically by the audience when she warned Conservatives that "they might become such a shiny bright new party that no one will recognize the true Conservatives in it." (The Times, 11 September 1965)

1980: 35) 
A very concrete illustration of his propensity to ignore tradition was his decision to convert the party to devolution in Scotland. (Bogdanor, Devo) In May 1968, attending a conference of the Conservative Party in Perth, Heath announced that he would support the creation of a devolved assembly in Scotland. This would later be known as the Declaration of Perth, a major turning point in the Conservative Party's approach to the Scottish question. The Conservative Party had been heretofore a staunch defender of Unionism (the full name of the Conservative party being the Conservative and Unionist Party), therefore committing the party to the principle of Home Rule in Scotland was a revolutionary move. (Bogdanor, 1979:Devolnside the party there had been no consultation, only a few Shadow Cabinet members had heard of his intention, and everyone was presented with a fait accompli they should swallow without wincing. Was this risk-taking, authoritative decision-making or simply opportunism in the face of poor electoral results in Scotland? The answer lies in the three elements. There was a dose of opportunism in this pledge as Heath had never before really paid attention to the Scottish question, but the victory of the SNP a year earlier at byelections clearly precipitated this decision. It was also authoritative decision-making considering that he had not consulted his backbenchers before but Heath also enjoyed the image of the risk-taker, the man who took tough decisions to carry the party forward. (Ball and Seldon, 1996: , 21thscribes himself as "a doer" and he saw it as a waste of time to spend endless hours discussing the topic. (Heath, 1998:p. 18) When he was convincede could be in the lead on some questions he ignored the party and imposed his views. He acted independently in order to associate the party to a radical departure which would show its capacity for innovation and progress, especially on such a major constitutional issue. (Ball and Seldon, 1996: 21)Bogdanor, 1979:p. 81)

But it was not long before Heath met the massive resistance of the party. His modernising ambitions and ruptures from the Conservative tradition were a growing concern among Conservative MPs and some of them voiced their discontent in a forceful manner.

\section{II) Disjunction: the collapse into indecision and elusiveness}

Heath had been elected, as such it gave him an undeniable legitimacy. After the much controverted emergence of Douglas-Home as leader in 1963, the election had been precisely aimed at giving "an aura of authority over the Parliamentary Conservative Party and a 
perception of legitimacy as leader of the Conservative Party.” (Heppell, 2008: 49) But legitimacy and authority are not equal and do not derive from the same sources. An election cannot give the natural authority that radiates from a charismatic and inspiring leader. Legitimacy, in Heath's case, was the result of the election. In Max Weber's terminology, his domination of the party was a rational legal process. (Weber, 1995: 285) Authority, or "charismatic leadership", on the other hand, has a more irratural dcess, that it hawith the extraordinary qualities and skills of a man or /woman, hence Weber's concept $f$ "charismatic domination". (Weber natural authority thereforefand devotioa leader naturally inspires/commands. Besides, anncannot transform a shy and lacklustre man into a natural born leader. "a certain quality of an individual personality,a

During his years as leader, Heath met considerable resistance from the traditional imperialist right and considerable hostility from those who refused the monopoly of modernisation. In The Winds of Change, John Ramsden explains that many Conservatives were hostile to this rhetoric of modernisation and change "simply because they were natural conservatives who did not therefore see it as their Party's business to preach the opposite." (Ramsden, 1996: 11) Dominic Sandbrook adds that "Heath's appeals to modernisation, rather than to tradition, did not fire up the Tory faithful." (Sandbrook, 2006: 159) The difficulty for Heath is that he was elected at a major time of transition. The party had lost two general elections successively, it had to adapt to the status of a party of Opposition, it also had to adapt to a society in flux. Defeat, introspection, anxiety: all these ingredients combined together provoked a Tory malaise that Heath, as leader, was supposed to allay and cure. For a great leader, this challenging and stimulating situation would have been an opportunity for excellence; for an awkward leader like Ted Heath those exceptional circumstances simply overwhelmed him. T periods in opposition

During his years as Leader of the Opposition - from 1965 to 1970 - Heath faced a struggle between tradition and modernisation and was caught between several antagonist movements inside his party: new economic models were emerging and appealed to those who had grown exhausted of the post-war consensus. Andrew Gamble in The Conservative Nation, dedicates a whole chapter to describe the "growing ideological offensive of the New Right, p. he party.” (Gamble,' 1974:p. 104) The New Right blamed the post-war consensus for the economic declineof thenited Kingdom and perceived it as nothing but a toned-down version of Socialism begetting a whole lot of evils: immigration, crime, violence, 
permissiveness and decadenceeconomic decline. (Gamble, 1974:p. 111) To the proponents of the New Right, the : 'one of the most c fe New Right.' Increasinll the evils blighting Britain. (Gamble, 111), post-war settlement: a teddical new course that br

Others considered that progress was possible only through the maintenance of the Welfare State and the guarantee of cohesion and protection. (Gamble, 1974: 99) In foreign politics too, conflicting stances vied with each other: the imperialist right wing best represented by people like Lord Salisbury or the Monday Club ${ }^{7}$ nisation in Africa) clutched at the idea of itain while for others Britain's future could only lie in a strong union with Europe. (Ball and Seldon, 1996: 215/229) Dealing with the party's heritage and at the same time handling the party's modernising spirit proved too difficult for Ted Heath. Thus, if repudiation characterises Heath's leadership at some points - disjunction, thatdisjunction, which is the inability to adjust to a party's past legacy according to Stephen Skowation of leadership - also casts light on Heath's leadership as he failed to master the combination of continuity and change that makes the essence of the Conservative Party.

On many questions there was no doubt where Heath stood but faced with opposition and resistance Heath backed away in order to avoid conflicts. Also, when debates proved too divisive and inflammatory, he refused to resolve the question and eluded the subject. The difficulties of exercising power revealed the true nature of Heath's leadership: weakness, indecision and elusiveness. It was not so much a search for consensus as incapacity to decide and confront his party. It also revealed a lack of courage: elusiveness was preferable to direct confrontation but isn't it the primary responsibility of a leader to confront his party when necessary?

One major episode - Rhodesia - clearly exemplifies Heath's difficulties in dealing with the party's past and enduring opposition from his colleagues. The Rhodesian crisis started only a few months after Heath's election. It represented the first act of provocation from the imperialist right and the first attempt to undermine his authority as leader. Many Conservatives had close emotional or family links with the former countries of the Empire, and the subject was highly sensitive as it involved a variety of feelings. Heath, as far as he was concerned, was totally impervious to the nostalgia or attachment that others in his party could feel. No one in his family had lived overseas and it was not before the 1960s that Heath first visited a Commonwealth country. (Hdouglas hurd, 1979: p. 41): His own family backgrou course beistinctly unimpera felt “neither the 'kith and kin' feeling of the tradi: 193) His beliefs inIt The old imperialist right: Lord Salisbury, the Monday Club (a righreign

\footnotetext{
7 The Monday Club was a right-wing group formed in the early 1960s?to oppose decolonisation in Africa.
} 
politicsionalso explain his detachment from the Commonwealth. Clearly, Heath's stood in stark contrast with people in his party and more largy of his fellow countrymen. Douglas Hurd affirms in his mdeal for Europe and nothing for the rest of the world.) The statement may seem extreme but it is nonetheless accurate as reg, New Horizons. In h autobiography, he reaffirmed his belief that nostalgia could not "blind us to the real needs of our nation" (Heath, 1998:p. 225) and that "our future lay in our own continent and not in distant lands which our forefathers had coloured pink on the map." (Heath, 1998:p. 177)

Problems occurred when Ian Smith declared the unilateral independence of South Rhodesia on 11 November 1965, an illegal decision that Harold Wilson immediately condemned. He first announced a series of economic sanctions before hardening his position and imposing in December an embargo on oil which would deprive Rhodesia of this precious source of energy. Heath also condemned the declaration of independence but refused to go further and used a very moderate vocabulary to refer to the new Rhodesian government. His natural sympathies lay with the more progressive branch who condemned the racist and authoritative government of Ian Smith. Heath abhorred all acts of racial discrimination but he never clearly articulated it as he knew that an important branch of his party supported Smith and the white settlers in Rhodesia. The letters sent to the CCO at the time of the crisis testified of the massive support of Conservative Party members for Ian Smith. So when it came to take a decision on the Labour government's sanctions, Heath chose the most unsatisfying decision: "limited but not punitive actions. The ambiguity of his position was accentuated by his decision to choose abstention on the vote on the oil embargo. (Ball and Seldon, 1996: 229) His wish to maintain unity was crushed down as eighty Conservative MPs refused to follow their party's line and voted against the sanctions. (Hansard, 21 December 1965, 722/1889) It was clearly from one branch of the party an act of betrayal and disloyalty. The divisions in his party were now exposed publicly in spite of his efforts to try and maintain unity. He was blamed for this disastrous spectacle and it was now obvious that he did not show enough authority and charisma to impose his views on the party. Here is how Tony Benn described Heath after the debate in Parliament: "Heath is a pathetic figure, kicked this way and that, and is incapable of giving firm leadership. Home and Selwyn Lloyd are really running the Tory party now." (Benn, 1988: 354)

Heath was at a loss with this subject which was so far from his convictions, commitments and causes. To him, Rhodesia was an irrelevant waste of time and a serious brake on Britain's move towards modernity. p. 41) He confessed in his autobiography that 
Britain's "powerful, almost overwhelming hal background is still the main obstacle to modernisation in this country." (Heath, 1998:p. 258) Only Europe mattered to him and only Europe could guarantee the future of modern d prospeost ppe had beech at the House of Commons in $1 \mathrm{ffirm}$ his position to his opponents inside the party ut ., the only future for Britain lay in a union with the Common Market.

the search for unity prevailed over the expression of his deepest convictions. As Denis MacShane suggests "the leader for whom unity predominates is the leader who ends up unsure how to lead." (MacShane, 2006: 52) This comment sheds an interesting light on the position ofthe tween leadend led. A leader is expected to lead and that inevitably implies a degree of autocracy and, domination. This is also e argument raised in Jean-Claude Monod's book, Qu'est-ce qu'un chef en démocratie?to take decisions, to assernd not to feaf a feis involves a degree of autoctruggle between two antagonist trends." (Mond, 2012: 43) $\mathrm{He}$ suggests in his study that a democratic leader is an impossible concept, almost an oxymoron, and he highlights the tension of contemporary politics which extols democracy as the greatest form of government and yet is constantly in search of charismatic leaders. (Monod, 2012: 17, 31) It also highlights the aninteresting tension between the reverence for democracy and the seemingly inevitable almighty position of the leader. Thus, the Weberian definition of the leader as being above the hrerfectly relevant despite liberal progress as if there were, fundamental unchanging elements in the nature of leadership. This is the main argument put forward by Jean-Claude Monod in Qu'est-ce qu'un c

Heath's main fear was that the Rhodesian crisis could destroy the unity of the party as the Suez crisis had done a few years earlier. Heath was a whip at the time of the Suez crisis; he had been a witness of the havoc wrecked by this episode. The remembrance of those dark hours mitigated Heath's reaction: instead of asserting his position and clearly expressing his views, he chose a tepid in-between solution that did not satisfy anyone and did not resolve the tensions. At the time, he was not lauded for his sense of compromise; he was condemned for his weakness and indecision. As the journalist Robin Day pointed out to him, "the party expects a more vigorous, pungent, red-blooded form of leadership." ${ }^{9}$

\footnotetext{
${ }^{8}$ My translation. 
This first episode announced and foreshadowed the other crises that blasted his years as Leader of the Conservative Party. Rhodesia is perhaps the most spectacular in the sense that the party was openly divided and a great number of MPs refused to vote according to instructions. It is also one of the most interesting to study as it involves the passions and fears of the Conservative Party: the attachment to the Empire, respect for the past, the reluctance and resistance to change. Heath's incapacity to take side in a debate was again revealed on the delicate issue of incomes policy. The party was divided between the supporters of incomes policy and the antis, but Heath preferred to simply ignore the subject and wait until he was in power to decide on the relevance of incomes policy. This was Edward Heath at his worst: choosing escape rather than debate. No serious leadership has ever been achieved on such inconsistent behaviour and the severity of the criticisms against him originates from this major weakness.

Andrew Gamble argues that "The crisis of leadership in those years was thus at the same time a crisis of ideology." (Gamble, 1974: 91) The major problem at the heart of the Conservative Party was that to the public at large Heath had no clear political identity: too many hesitations, a discrepancy between words and actions, a difficulty to define his political stance had blurred the political message.

\section{III) The deconstruction of Heath's leadership}

John Ramsden explainsexplains in The Winds of Change that many of the problems "had to do with Heath himself, as a personality, as a manager of the Party, and as a controller of the debate about the future policy options." (Ramsden, 1996: 243) What this statement simply reveals is that Heath was no man to become one day Leader of the Conservative Party, let alone Prime Minister. The daily exercise of power brought to light the huge chasm between his alleged talents and the mediocre reality of his leadership. Heath had many qualities: he was determined, he was energetic, and exceptionally hard-working. All of these are professional qualities but his central, crippling handicap was that he lacked the charisma that radiate from the great men and women. It is a simple truth but an election cannot transform a shy and lacklustre man into a natural born leader. As we saw before, Weber's definition of charismatic leadership rests on a series of exceptional qualities that set the leader 
apart, and especially above, ordinary men. (Weber, 1995: 285) Eloquence, self-confidence, a sort of 'magic touch' with the people can be among those qualities, but Heath had none of these. He was a shy and introvert man who felt highly uncomfortable talking in public and was unable to inspire enthusiasm in the audience. (Hurd, 1979: 11) It is crucial, I think, to emphasise the power of good communication skills in the construction of great leaders. Most of the major historical figures marked their times with famous speeches that had a worldwide echo. The power of words in politics should never be underestimated and Heath's uneasiness with words partly explains his failed leadership.

"Conservative MPs can be heard asking 'Have we all made a terrible mis

The first eminent member of the Conservative Party to publicly express his bitterness and disappointment was Angus Maude, a representative of the New Right, in an article entitled 'Winter of Tory Discontent'. In this article, Maude unleashed a scathing criticism of the way Heath ran the party blaming him for his incapacity to show strong opposition to Wilson and to lack "the Tory instinct for survival [which] depends on an ability to discern in doubtful situations what the people of this country really want." The opening paragraph of his article encapsulates the gist of his grievances:

\begin{abstract}
"It is obvious that the Conservative party has completely lost effective political initiative. Its own supporters in the country are divided and deeply worried by the failure, while to the electorate at large the Opposition has become a meaningless irrelevance." (The Spectator, 14 January 1966)
\end{abstract}

A week after, a Conservative Party member from Sunderland sent a letter to the CCO in which he wrote that "The truth of Mr Angus Maude's opening paragraph cannot unfortunately be questioned." (CPA, CCO 20/8/9, 20 January 1966) Maude's article is a very severe portrait of Heath's leadership but it also contained an element of truth when the article blamed Heath for speaking like a technocrat. Ted Heath was indeed said to be a perfect technocrat: a lover of figures and tedious details who felt more comfortable with the civil servants in Whitehall than with his colleagues in the House of Commons. ${ }^{10}$ Heath's place was in the background, in the shadow of great men, working on policy-making and administration. Not everyone can be a great leader but Heath simply was no leader at all. He was not a leader of men, of ideas, of change. He was overwhelmed and crushed by the prominence of the role and the weight of this exceptional position. And his former followers were dismayed by his

\footnotetext{
${ }^{10}$ When Heath became Prime Minister and political pressure started to grow around him, he got very close to Robert Armstrong, a senior civil servant, who came to be known as the 'Deputy Prime Minister'.
} 
incapacity to provide a satisfying leadership. A group of young Conservatives from Lewes included a motion on the agenda of their meeting which stated:

"This house believes that the present leadership of the Tory Party is not inspiring to Party members nor to the Nation and urges that steps should be taken immediately to provide this inspiration." (CPA CCO 4/10/150, 3 February 1967)

The key word of this statement is 'inspiration'. Heath was not an inspiring leader and his programme was too technocratic to secure the enthusiasm of the people. With Heath, no lyricism, no flame, no panache. (HURDurd, 1979: 1. 10-13) His aim was to awaken people and show them the dire reality of their country. He alarmed people but he did not propose, as a compensation for the sinister picture he drew, an exciting project for Britain. The leader must be first and foremost an inspirer before being a doer and a thinker. He must inspire positive feelings such as enchantment, confidence and enthusiasm. He must be a myth-maker who takes people to another dimension, a dimension in which hopes and dreams are allowed in order to envisage a better life and a better tomorrow. And finally, the leader must create a positiveA narrative tht appeals both to the people and his own party. (Heppell, 2008: xiii) But this was not Heath's conception of leadership and politics. He had a too puritan and lofty vision of his mission to envisage a change of attitude. His favourite posture - and this is the one he always kept until the end of his career in 2001 - was that of the truth teller. Heath was the politician who told people the plain and unvarnished truth. This attitude is revealing of Heath's seriousness and integrity but inevitably it resulted in a disastrous effect in terms of public image. Also, opinion polls showed that people found him a cold and dry man. ${ }^{11}$ As The Times underlined, "in the regard of the British public he has remained a strangely colourless figure with an elusive political personality." (The Times, 16 May 1970)

Heath's leadership was a non-entity and left a dangerous vacuum that worried Conservative Party members, as the following letter highlights: "One looks in vain for a leader at the head of the Conservative party." (CPA, CCO 4/10/150, 30 November 1967) But like nature, a political party abhors a vacuum. Enoch Powell, one of Heath's main rivals inside the party who had run against him for the leadership of the Conservative Party, exploited this vacancy and sought to fill in the ideological and personal chasm created by Ted Heath. In 1968, the sudden popularity of Enoch Powell represented a real challenge to Heath's leadership. He imposed a real new tone and a new discourse in the national political debate. 
Overnight, Powell became the central figure of British politics with the "Rivers of Blood" speech but his provocations started well before April 1968 and one of them is revealing of his attempt to undermine and discredit Heath's leadership. In 1966, Heath entitled the Conservative manifesto for the general election Action Not Words. A few days later, Powell published his own manifesto entitled Words Not Action. This episode which, at first glance, could look insignificant was actually a biting attack against Heath and an explicit reference to the lack of dialogue and debates inside the party.

The "Rivers of Blood" speech is the most emblematic episode of the confrontation between the two men. The speech described in apocalyptical terms the dangers of massive immigration in the United Kingdom and the potential disintegration of Britishness. Powell was immediately sacked from the Shadow Cabinet but became overnight the hero of the working class, the defender of the most destitute and fragile people, the spokesman of the silent majority. Powell's feat was to be able to speak to a whole range of people who were usually totally impervious to the Conservative Party's message. He did not speak like them but he spoke for them and everyone could feel familiar with the anecdotes he related in his speeches. Whereas Heath used the dry language of the technocrat, Powell brilliantly handled the language of the populist.

The effects of Powell's speech and popularity were momentous. Powell became the arbiter of the ideological debate and magnified the insignificance of Heath's leadership: he set the tone and forced Heath to change his language and adopt a different position. For instance, just a few months after the "Rivers of Blood" speech, Heath explained in a speech in York that "the number of immigrants entering Britain [...] must be severely curtailed." "2 (CPA, PPB 1617, 20 September 1968) His attempt to 'steal' Powell's favourite theme was so obvious that he lost all credibility. In For Conservatives Only, Lord Coleraine writes that "Those who set the trend, not those who reflect it, have the real power." (Lord Coleraine, 1970: 12) Heath was the leader of the party but he was not the intellectual, moral and spiritual driving force of the party. He never set the trend, he did try to impose a new discourse but he failed because it was too technocratic and dry. He was unable to communicate his project in a simple and appealing language, hence the divorce between him and the rest of the nation. Only before the general election did he succeed but here again histhe succe(as in 1965) rested on a major misunderstanding. While for five years he had been completely deconstructed by the pressures of Opposition, he was suddenly reconstructed in the words of Harold Wilson who 12 
nicknamed him 'Selsdon Man' after a. sSpeechhe ave after the Selsdon Park Conference on which he reaffirmed right-wing themes: public spending cuts, emphasis on tax cuts, seleocial services, reform of trade unions and above all, two words which caught attention: law and order. (Blake, 1985: 307) Wilson immediately condemned this speech as aA direct attack on the pos-war consensus but unexpectedly it workedplayed in Heath's favour thson denounced/co a Thus, the dull and unidentifiable leader became the tough man bent on imposing law and order. 'Selsdon Man' was a grotesque political mask, a device to attract more voters on the right but deep down Heath fundamentally remained a One Nation conservative. For the second time he endorsed a costume that was not his and endorsed a political identity so far estranged from what he really was. But this character was more appealing than the real man and the 'law and order' discourse more exciting than his highly complexdry technocratic programme. In Ted Heath's career, ible only if he misrepresented his political identity and failure came inevitably when the exercise of power unveiled his real nature.

The real tragedy of Edward Heath's leadership is that he was an inspired leader with great ambitions but totally uninspiring to the public. He was a moderniser, he was a determined and hard-working leader but he never managed to secure the enthusiasm of his party and never managed to communicate his vision to the nation. He was not liked nor understood and his two elections are the result of profound misunderstandings on his political personality; finally, as far as his legacy is concerned, apart from Britain's entry into Europe his great historical success - he achieved none of his promises and ambitions. The failures and prevarications of a leader are extremely instructive for an historian as they provide an illuminating insight to unravel the complexities of political leadership. Whatever the epoch, whatever the mode of designation, whatever the party and the country, there are unchanging fundamental elements about the nature of leadership: an ability to manage different coalitions inside a party, a clever balancing between tradition and change, and above all a natural authority that commands the devotion, respect and loyalty of the party. (Weber, 1995: 320) But, to me, there is one final element that transforms any leader into a great leader: the encounter with history. Leadership is this ability to create a new narrative,s to impose new economic or intellectual models and to change the course of history. (Heppell, 2008: xiii) In spite of his central leading position, Edward Heath never dominated the national debate or controlled the set of events. He was a plaything in the hands of history, never its master. While the Conservative Party reveres its great figures, Edward Heath suffered the cruel destiny 
reserved to the losers and minor transitional figures: the fall into oblivion and historical obscurity.

BIBLIOGRAPHY

\section{Primary sources}

- Conservative Party Archives

PPB 12: Speeches by Edward Heath, 1964-65

PPB 16-7: Speeches by Edward Heath, 1968-69

CCO 4/10/150: Criticism of leader, 30 November 1967

CCO 4/10/152: Heath's message, 15 December 1967

CCO 20/8/9: Correspondence with Edward Heath, 20 January 1966

CCO 20/8/10: Correspondence with Edward Heath, 12 June 1967

CCO 20/8/12: Correspondence with Edward Heath, 8 July 1968

CCO 600/12/7: Putting Britain Right Ahead, A Statement of Conservative Aims, London, Conservative Political Centre, 1965.

LCC papers: 1970

- British Press

The Economist, 31 July 1965

, 9 October 1965

, 28 January 1968

The Spectator, 15 October 1965 
The Times, 11 September 1965 ,23 April 1968 16 May 1970

- Official publication

Hansard, 21 December 1965, 722/1889

- Autobiographies, memoirs and diaries

BENN, T. (1988), Out of Wilderness: Diaries 1963-1967, (London:, Arrw), 1988

HEATH, E. (1988), The Course of My Life, (London:, Hodde \& Stoughton), 1998.

HURD, D. (1979), An End to Promises, Sketch of a Government 1970-74, (London:, Collin), 1979.

\section{Secondary sources}

BALE, T. (2010), The Conservative Party from Thatcher to Cameron, (Cambridge (Maolity).,2010

BALL, S., SELDON A. (eds.) (1996), The Heath Government 1970-1974, A Reappraisal, (London and New York: Longman).

BALL and SELDON (eds.) (2005), Recovering Power. The Conservatives in Opposition Since 1867, (Basingstoke and New York: Palgrave Macmillan). 
BLAKE, R. (1985), The Conservative Party from Peel to Thatcher, (London: Fontana Press)., 1985

BOGDANOR, V. (1979), Devolution, (Oxford: Oxford University Press).

CAMPBELL, J. (1993), Edward Heath, A Biography, (London: Pimlico).

Lord COLERAINE (1970), For Conservatives Only, (London: Tom Stacey Ltd.).

FREEDEN, M. (1996), Ideologies and Political Theory, (Oxford: Clarendon Press), 1996.

GAMBLE, A. (1974), The Conservative Nation, (London and Boston: Routledge \& Kegan Paul).

GREEN, E.H.H (2002), Ideologies of Conservatism, Conservative Political Ideas in the Twentieth Century, (Oxford:, Oxfor University Press), 2002.

GREENLEAF, W.H. (1983), The British Political Tradition, vol. 1: The Rise of Collectivism, (London:,Routledge)., The British Political Tradition, vol. 2: The Ideological Heritage,

(London:,Routledge).

HEATH, E. (1968), Old World, New Horizons. Britain, Europe, and the Atlantic Alliance, (Cambridge: (Mass.d University Press)., 1968

HEPPEL, T. (ed.) (200Choosi the Tory LeaderLeaders of ive Party Leadership Elections from Heath to Cameron, (London and New York:Basingstoke and New York:, Palgrave acmillan ,

JESSOP, B. (1974), Traditionalism: Conservatism and British Political Culture, (London: Allen \& Unwin)., 1974 
LAYTON-HENRY, Z. (ed.) (1980), Conservative Party Politics, (London and Basingstoke: The Macmillan Press Ltd.).

1 Decisions :Decisions: LeadPolicymakinananagement,

MACSHANE, D. (2006), Heath, (London: Haus Publishing).

MONOD, J-C. (2012), Qu'est-ce qu'un chef en démocratie? Politiques du charisme, (Paris: Editions du Seuil).

NORTON, P. and, Ar, A. (1981), Conservatives and Conservatism, (London:, Temple Smith), 181.

RAMSDEN, J. (1980), The Making of Conservative Party Policy. The Conservative Research Department Since 1929, (London and New York: Longman).

(1996), The Winds of Change, Macmillan to Heath 1957-75, (London and New York: Longman).

ROTH, A. (1972), Heath and the Heathmen, (London: Routledge \& Kegan Paul).

SANDBROOK, D. (2006), White Heat, A History of Britain in the 1960s, (London: Abacus).

SCRUTON, R. (1980), The Meaning of Conservatism, (London: Macmillan)., 1980

SKOWRONEK, S. (1993), The Politics Presidents Make: Leadership from John Adams to George Bush, (Cambridge: Harvard University Press).

WEBER, M. (1995), Economie et Société, (Paris :, Pln), 19 (1958), Essays iology, 